\title{
Tax-in or Tax-out? Evidence from the Relation of Financial Performance and Effective Taxation of Czech Subsidiaries under Foreign Control
}

\author{
David Prochazka
}

University of Economics, Prague

W. Churchill St. 4; 13067 Prague; Czech Republic

E-mail.prochazd@vse.cz.

cross $^{\text {ref }}$ http://dx.doi.org/10.5755/j01.ee.30.3.20281

\begin{abstract}
The paper's aim is to investigate whether foreign direct investors (namely companies listed in the EU) tax their group profits in the Czech Republic through the local subsidiaries or whether profits of Czech subsidiaries are taxed outside the country. The analysis of tax behaviour is based on the assessment of the relation between financial performance and effective tax rates reported in the financial statements of Czech subsidiaries. Descriptive statistics shows that the effective taxation of Czech subsidiaries under control of foreign listed parents is significantly lower than for other Czech companies. Furthermore, the method of Conditional Inference Trees reveals significant variability in relative tax rates suggesting that the majority of foreign parents from western and northern EU countries prefer to tax profits in the Czech Republic rather than elsewhere. Shifting profits to the Czech Republic results in superior reporting performance of the affected subsidiaries. In contrast, empirical evidence also shows that parent companies from southern EU countries seek ways to avoid taxation. The unclear tax motives of both parent company groups hinder an appropriate assessment of the financial performance of subsidiaries from being conducted by external users.
\end{abstract}

Keywords: Financial Performance; Effective Tax Rate; Parent-Subsidiary Links; Czech Subsidiaries; Foreign Control.

\section{Introduction}

Researchers and policy makers constantly strive to find the answer to the fundamental question of whether accounting income and tax profit are to be aligned or treated separately. Income is distributed both to owners and government, therefore, the calculation of distributable income shall follow similar principles in both systems to avoid capital erosion (Hicks, 1946). A contrary view is that accounting and taxation serve different purposes, so the subsequent merging of contradictory goals into a single concept of income will either harm the users of financial statements or threaten tax collection. The real systems of corporate taxation and financial reporting are, therefore, independent at some extent (Prochazka \& Molin, 2016). However, the dichotomy of both systems opens the floodgates for the opportunistic behaviour of managers who can improve the bottom line in income statement directed to capital market participants and, simultaneously, to reduce profits reported in their tax fillings significantly. Evidence of this can be seen in the behaviour of companies that engaged in accounting scandals at the turn of the millennium (Desai, 2005; Whitaker, 2005). More robust evidence (on larger samples of companies) of the increasing spread between accounting and tax profits is provided by Manzon \& Plesko (2001), Mills, Newberry \& Trautman (2002) and Dyreng, Hanlon \& Maydew (2008). Frank, Lynch \& Rego (2009) indicate that there are insufficient compliance costs to ensure a trade-off between accounting and tax aggressiveness. In fact, companies can exercise a strong financial, as well as tax reporting, aggressiveness as they manage book income upwards while decreasing their taxable profit. The calls for higher book-tax conformity (i.e. for a tighter link between accounting and tax profit) seem to be a logical response to tackle the double-opportunistic behaviour of companies (Desai, 2005).

Several research studies cast doubts as to whether the alignment of tax profits with accounting income can discourage companies from aggressive tax behaviour. Firstly, the subordination of accounting to tax purposes lowers accounting quality, thus impairing the effectiveness of financial reporting for economic decision-making by external users (Ali \& Hwang, 2000) as the earnings become less informative then (Hanlon \& Shevlin, 2005; Hanlon, Laplante \& Shevlin, 2005; Hanlon, Maydew \& Shevlin, 2008; Atwood, Drake \& Myers, 2010). Secondly, if tax aggressive companies face high book-tax conformity, they are enticed to lobby strongly on accounting standards to ensure a more favourable tax regime (Hoffmann \& Zulch, 2014). Such inferences into accounting principles decrease the quality of financial reporting even when non-aggressive companies have strong reporting incentives to provide useful information to investors and other stakeholders. Thirdly, empirical evidence from countries with strict legal regimes pursuing a high level of book-tax conformity reveals that companies engage in aggressive tax optimisation even under tight tax rules (Lang, Lins \& Maffett, 2012; Blaylock, Gaertner \& Shevlin, 2015), e.g. through foreign subsidiaries, once again with negative impact on accounting quality (Durnev, Li \& Magnan, 2017).

Regardless whether the approaches relying on tight book-tax conformity are vital or not, the existence of tax avoidance is a matter of fact. Watrin, Ebert \& Thomsen (2014), having investigated consolidated and separate financial statements of companies from $27 \mathrm{EU}$ countries, provide ample evidence about earnings management, both 
in countries with high and low levels of book-tax conformity, notwithstanding the extent of earnings management being lower for the first group. The complexity of the problem increases due to the presence of multinational enterprises (MNE) in the local economy, as international mobility of capital facilitates the evasion of corporate taxation (Diamond \& Mirrlees, 1971). Companies engaged in international activities with subsidiaries distributed worldwide can easily transfer profits from one country to another via transfer pricing and other within-thegroup transactions. Huizinga \& Laeven (2008) and Heckemeyer \& Overesch (2013) document a substantial response of profit measures to international tax rate differentials; the magnitude depends on the tax base shifting semi-elasticities of the parent and subsidiary country tax regime. Tax optimisation within MNEs can also be eased by the adoption of the International Financial Reporting Standards (IFRS). Using data from the EU-based companies for the period 2001 to 2010, De Simone (2016) identifies a significant $16.2 \%$ tax-motivated change in reported pre-tax profits following the IFRS adoption by multinational entities, in comparison to no material change in opportunistic tax behaviour of companies reporting under local accounting standards. The IFRS adoption has alleviated tax discipline.

Tax avoidance by MNEs can be a severe problem for tax collection in small open economies where a significant share of foreign entities on the ownership of domestic companies may exist. The parent company can pursue either value-creation (positive) or value-exploitation (negative) goals when acquiring a (foreign) subsidiary (Yang, Mudambi \& Meyer, 2008). If the first case is relevant, a positive impact on the subsidiary's performance can be expected (Fang, Wade, Delios \& Beamish, 2007; Gaur, Delios \& Singh, 2007; Fang, Jiang, Makino \& Beamish, 2010), in particular when the parent is domiciled in a developed country and the subsidiary is operating in an emerging market. The transfers (know-how, staff, and technology) from the parent and its commands usually reshape the organizational structure of the subsidiary and improve its performance (Fey \& Bjorkman, 2001; Luo, 2003). In many cases, such subsidiaries are the largest companies in the local economy (Albu, Lupu \& Sandu, 2014), thus creating benchmarks for other companies not only in terms of financial performance, but also in regard of corporate governance, including tax discipline.

A significant share of these subsidiaries is owned by parent companies whose securities are traded in capital markets. Listed companies are required by investors to generate reasonable returns on investments while simultaneously finding themselves under significant pressure to ensure a high level of corporate governance within their groups. However, capital markets do not always operate in an effective manner. Any notion of weak enforcement can entice companies to manage key performance indicators opportunistically and the unclear incentives of the parent's management can have unpredicted effects on the activities and performance of subsidiaries (Berman, Wicks, Kotha \& Jones, 1999; Orlitzky, Schmidt \& Rynes, 2003). Furthermore, the reaction of subsidiaries to such institutional duality (Kostova \& Roth, 2002) is not predictable (Oliver, 1991). The value flows within "parent- subsidiary links" can, thus, embrace various motivations, not distinguishable by outside parties. By the very definition of control, the parent company has power to influence the operations of its subsidiary, including because of tax optimisation. Any discretionary profit shifting into a subsidiary or off-subsidiary can severely change the true and fair view of the individual financial statements of the subsidiary. Consequently, there is considerable risk that the users of subsidiary's financial statements may, subsequently, make misguided decisions based on the distorted financial data. Yet, rarely are attempts made to investigate the relation of effective taxation and financial performance as reported in the financial statements of companies controlled by other entities.

Literature review reveals two important outcomes of the presence of foreign direct investors in a small open transiting economy. Firstly, foreign investors contribute to boosting the performance of domestic firms. Secondly, parent companies are tempted to utilise their international operations to optimise the group taxation. Profits can be shifted either to the subsidiary or out of the subsidiary, based on the tax rate differentials between the parent's and the subsidiary's country. This paper investigates the pattern of subsidiary taxation on an example of the Czech Republic. Thanks to its suitable geographic location, skilled labour force and great tradition of manufacturing, the Czech Republic is an attractive place for foreign firms to establish large-scale plants and factories. Companies under foreign control generate approximately $50 \%$ of the Czech industrial output (Ernest, 2014) and contribute, thus, to a massive dividend outflows (Kucera, 2015). This paper attempts to find the solution to the puzzle, whether the Czech Republic is a country whereby profits are taxed-in or taxed-out. In particular, the objective of this paper is to reveal whether there is any common pattern in profit-shifting in the Czech Republic: whether foreign direct investors tax their group profits in the Czech Republic through the local subsidiaries or whether profits of Czech subsidiaries are taxed outside the country. As taxation shall interact with performance, the analysis of tax behaviour is based on the assessment of the relation between financial performance (measured by ROA and ROE) and effective tax rates (ETR) reported in the financial statements of Czech subsidiaries.

Unlike previous studies in the field (Huizinga \& Laeven, 2008; Heckemeyer \& Overesch, 2013; Bonacchi, Cipollini \& Zarowin, 2018), this paper works only with individual financial data of subsidiaries. Mentioned studies utilise data from both consolidated statements of a parent company and individual financial statements of its subsidiaries to identify tax optimisation. However, if a MNE is engaged in profit shifting, then individual financial statements cannot result in a true and fair view of economic reality, as they are distorted by artificial transactions through various profit-shifting channels. The relation between individual and consolidated figures can be biased and reliable estimates, e.g., in regression analysis, are in question. For this reason, the paper exploits only data on performance and effective taxation, as dependent variables, from individual financial statements of the subsidiaries. Furthermore, the explanatory variables are restricted only to those which cannot be manipulated by profit shifting, namely country domicile of the parent (as used by other 
studies) and industry affiliation of the subsidiary as an additional factor having power to explain the cross-sectional variation in performance and taxation.

The paper applies two research methods, ANOVA test and Conditional Inference Trees. The second method combines the approaches of regression modelling and cluster analysis. Such a combination enables not only to determine the statistical significance of explanatory variables, but also to identify subgroups of observations with a similar pattern of behaviour. Applying both methods to empirical data from financial statements, the results indicate that the subsidiary's industry interacts with the parent's domicile as far as the subsidiary's performance is concerned. However, the effective tax rates of Czech subsidiaries under foreign control are a prevailing function of the parent's domicile and the industry affiliation does not matter. Furthermore, Czech subsidiaries under control of the parents domiciled in Western and Northern Europe report higher effective taxation than subsidiaries whose parents are listed in other EU countries. Our results extends evidence of Huizinga \& Laeven (2008), who focus on country-tocountry differences without detail investigation of similarities among parent companies from different countries. The novelty of findings has important practical implications. The decision to transfer profits abroad or from abroad is always microeconomic (i.e., the decision is made in the firm's discretion). However, the knowledge of similar tax behaviour patterns of sundry subsidiaries, but with the parent companies from the same geographic region, offers the governments an opportunity to fine tune the tax rules either to increase the motivation of certain foreign investors to tax their profits in the local economy, or to discourage other investors from hoovering the profits out without profits being taxed in the local economy.

The paper is organised as follow. Following the introduction, which is combined with the literature review, Chapter 2 develops research hypotheses, describes the sample selection and outlines the methods. Chapter 3 presents and discusses the results. The final chapter concludes the paper.

\section{Research Design}

\section{Research Hypotheses}

Based on the literature review in the introduction, the paper's goal is concretised into following research hypotheses:

H1: The characteristics (domicile, industry) of parent companies (listed in EU capital markets) affect the financial performance of their Czech subsidiaries.

H2: The characteristics (domicile, industry) of parent companies (listed in EU capital markets) affect the effective tax rates of their Czech subsidiaries.

H3: There is (significant) positive relation between performance and taxation.

The incentives to transfer profits are primarily driven by the differential in (effective) tax rate between the country of a parent company and the country of its subsidiary. In addition, there a lot of country- and company-specific factors supporting or restricting the incentives to transfer profits to the country with a more favourable regime.
Management compensation, tax compliance costs, leverage and debt covenants, earnings management strategy are examples of the most influential determinants. However, once a group decides to optimise taxation through profit shifting, individual financial statements are biased by presence of artificial transactions (without any justifiable economic background) or by applying transfer pricing which does not reflect faithfully the considerations exchanged in transactions between related parties. For this reason, research will always struggle with reliability of underlying accounting data. It is impossible to investigate each individual intercompany transaction whether it complies with the arm's length principle. Econometric models incorporating accounting measures (e.g. leverage) can, thus, produce false results, as researchers are not able to detect which companies are really involved in profitshifting.

To eliminate the influence of distorted accounting data, this paper focuses only on the domicile and industry of parent companies. Such an analysis is relatively rough, as it does not cover all potentially relevant factors. On the other hand, this approach is advantageous, as it does not require any assumptions about the tax behaviour and its impact on figures reported in financial statements. The domicile and industry are selected as explanatory variables for two reasons. Firstly, they are expected to influence both the financial performance and effective taxation of Czech subsidiaries, as evidenced by previous studies on related topics. Secondly, these factors are objective, and they are not subject of any manipulation. The clue to identification of profit shifting relates to the $\mathrm{H} 3$. There are two possible explanations of the expected positive association between performance and taxation of Czech subsidiaries. Firstly, the parents may seek value-creation goals by supporting their Czech subsidiaries with all possible know-how and other transfers as predicted by business research (Fey \& Bjorkman, 2001; Luo, 2003). Improved performance measured by ROA and ROE shall then be complemented with higher taxation. Secondly, parents may strive to optimise the group's taxation. The Czech taxation regime could be favourable and internal transactions can be processed in a way to ensure the profit transfer to Czech subsidiaries. The unjustifiable transactions from the market point of view (bringing one-side benefits to the Czech counterpart) may then result not only in higher taxes, but also in higher reported scores, although artificially higher, of ROA and ROE. If differences are identified, additional analyses are run to detect whether any similar pattern exists.

\section{Sample Selection}

Building upon the findings of De Simone (2016) and Watrin et al. (2014) concerning the rise in tax avoidance of European listed companies after adopting the IFRS, we focus only on the subsidiaries of the firms listed in the EU. This restriction has been introduced to keep the reporting incentives of the parent companies homogenous. A singlecountry study has been applied to hold sample companies reporting under the same set of financial reporting standards (Czech GAAP). This should ensure the ability to compare financial figures across the sample and eliminate any variation due to differences in the accounting regime used. 
Regarding the sample composition, several sources are utilised. The information on Czech subsidiaries of EU-listed companies is obtained from the Amadeus databased published by Bureau van Dijk. There are several imperfections when using the Amadeus for this purpose. Firstly, data on financial institutions are not included; secondly the database regards only the issuers of shares as listed firms but does not include bond issuers who must also comply with the Regulation (EC); thirdly, there are many mistakes made in the identification of companies. Using manual checks against the Business Register, the number of Czech companies under control of companies listed in the EU is determined to be 1,347 . The Albertina database is used to generate an extract from the financial statements of identified Czech subsidiaries. The analysis is processed for the period 2009 to 2014. The database contains 5,707 firmyear observations of annual reports. The following observations were deleted to obtain a more meaningful interpretation of effective tax rates and return on equity/assets: 142 observations with positive corporate income tax expense (because of prior period errors or postponed tax credits); 455 observations with negative equity; 1 case with negative assets. Furthermore, 57 observations without information on sales and 19 cases without earnings after taxation were dropped. The ultimate sample comprises of 5,033 firm-year observations and Table 1 outlines the descriptive statistics of selected figures from the financial statements for 2014.

Some extreme values are contained in the sample (e.g. RWE CZ is approximately three times larger than the next big firms). When compared to macroeconomic totals, the Czech subsidiaries under the control of EU listed companies have command over around $12 \%$ of the assets employed by the firms operating in the non-financial sector. Furthermore, they produce more than one quarter of the aggregate output of the Czech non-financial sector. Their macroeconomic reach is also confirmed by tax figures, as their share of corporate income tax collection is almost $20 \%$, an amount generated only by 1,347 companies which is less than $0.3 \%$ of all active Czech business enterprises. Aggregate figures highlight the economic significance of sample subsidiaries in the case of taxation, but descriptive statistics alone reveal huge discrepancies across companies. In total, there are 1,424 observations with zero income tax expense, meaning that over $28 \%$ of firms did not pay any taxes in a given year. Negative earnings before interest and taxation (EBIT) are evidenced in 824 cases; negative earnings before taxation (EBT) occur in 965 observations; negative earnings after taxation (EAT) occur in 988 instances.

Table 1

Descriptive Statistics of Czech Subsidiaries (Thousands CZK)

\begin{tabular}{lrrrrr}
\hline $\begin{array}{l}\text { Year 2014 } \\
\mathbf{n}=\mathbf{6 5 1}\end{array}$ & min & median & max & mean & sd \\
\hline Assets & 60 & 322,069 & $176,869,000$ & $2,749,574$ & $12,097,283$ \\
Equity & 12 & 128,348 & $121,549,206$ & $1,498,482$ & $8,227,410$ \\
Sales & 43 & 349,314 & $304,448,000$ & $3,092,191$ & $15,300,824$ \\
CIT & 0 & 2,437 & $1,624,081$ & 30,178 & 116,970 \\
EBIT & $(4,632,000)$ & 18,281 & $18,421,000$ & 209,560 & $1,006,460$ \\
EBT & $(4,887,000)$ & 16,791 & $18,421,000$ & 201,449 & 996,291 \\
EAT & $(3,995,000)$ & 13,799 & $18,421,000$ & 172,745 & 924,116 \\
\hline
\end{tabular}

Source: Author's analysis of data from the Albertina database

\section{Methodology}

The assessment of financial performance is performed by applying two standard metrics of financial analysis: Return on Assets (ROA) and Return on Equity (ROE). The ROE of i-company is calculated as the share of Earnings after Taxation (EAT) on the company's Equity. ROA is determined as the ratio between Earnings before Interest and Taxation (EBIT) and the firm's Assets. The ROE is selected as a basic measure of a company performance from the perspective of its owners. Contrariwise, ROA better depicts the performance in the context of all relevant capital providers.

$$
\begin{aligned}
& R O E_{i}=E A T_{i} / \text { Equity }_{i} \\
& R O A_{i}=E B I T_{i} / \text { Assets }_{i}
\end{aligned}
$$

The effective tax rate for i-company is computed as the ratio of Current Income Tax expense (CIT) divided by Earnings before Taxation (EBT).

$$
E T R_{i}=C I T_{i} / E B T_{i}
$$

Regarding research instruments, the existence of differences in performance and effective taxation will be tested using the method based on an analysis of variance, namely factorial ANOVA. Secondly, additional analysis of the existence of similarities in differences will utilise the methodology of Conditional Inference trees (CI trees). The CI trees belong to a group of decision trees which estimate a regression relationship by binary recursive partitioning into a conditional inference framework. The fundamental algorithm tests the null hypothesis of independence between any of the independent variables and the dependent variable. The explanatory variable indicating the strongest relation to the response variable is selected; the magnitude of the association refers to the p-value of a test for the partial null hypothesis of a single input variable and the response. Based on this association, a binary split in the investigated independent variable is processed. The procedure employs multiple significance tests computed repeatedly at each 
launch of the algorithm (Hothorn, Hornik, van de Wiel \& Zeileis, 2006); the permutation tests follow the paper of Strasser \& Weber (1999) dealing with the limit theorems for the conditional distributions of linear test statistics. The main advantage of using the conditional inference trees in this paper is that the method combines approaches applied by regression modelling and cluster analysis. Based on selected differentiating criteria (parent domicile and subsidiary industry in our case), the method enables to identify subgroups of units with a similar pattern of behaviour (financial performance and taxation in our case). The results do not show only those units which are significantly distinct, but they also indicate whether there are any similarities in these differences.

\section{Results}

\section{Basic Statistics}

As already stated, to obtain meaningful results on ETR, all observations with positive CIT are excluded. Analogous eliminations are made when calculating ROA and ROE. Finally, extremely high values of the resulting indicators (over $100 \%$ in absolute terms) ${ }^{1}$ were adjusted to avoid distortion, when summarising and interpreting the outcomes. In particular, if ROA, ROE or ETR is higher than $100 \%$, then $100 \%$ is taken as the ceiling. Accordingly, if any of the three measures are below (100\%), then (100\%) is used as the bottom figure.

A median for ROA is stable, oscillating around $7.2 \%$ with the average fluctuating from $8.6 \%$ to $11.2 \%$ over the years analysed. Similarly, the median of ROE is $12.2 \%$ and the average amounts to $13.4 \%$. ROE is significantly higher than ROA, thus resulting in the preliminary conclusion that profits of Czech subsidiaries might be taxed predominantly in the Czech Republic. However, the variability in ROE is two times greater when compared to the variability in ROA. The preference to tax the local profits (and, potentially, foreign profits as well) in the Czech Republic does not have to be an exclusive pattern for all MNE groups with subsidiaries in the Czech Republic. In this regard, the analysis unveils the relatively stable development of ETR, both for mean and median, ranging from 12.5 to $14.8 \%$ in the case of the mean and 16.3 to $17.7 \%$ in the case of the median. Both the average and median are significantly below the statutory legal tax rate, which is $19 \%$ (except for 2009, when the rate was $20 \%$ ). Furthermore, the average ETR for Czech subsidiaries under control of companies listed in the EU is well below the effective tax rate of 26.5 $\%$ computed to the total Czech economy (Svitlik, 2015). The ETR figures indicate a contrary conclusion from a mutual relation of ROA and $\mathrm{ROE}$, i.e., the parent companies manage earnings within the group to avoid taxation in the Czech Republic.

Table 2

ROA, ROE and ETR: Averages According to the Parents' Domiciles (in \%)

\begin{tabular}{lrrrlrrr}
\hline Country & ROA & ROE & ETR & Country & ROA & ROE & ETR \\
\hline Austria & 7.9 & 6.8 & 14.4 & Italy & 8.6 & 9.6 & 13.4 \\
Belgium & 11.0 & 10.9 & 10.4 & Luxembourg & 4.9 & 4.9 & 8.4 \\
Croatia & 4.7 & 9.0 & 22.9 & Malta & $(2.7)$ & $(35.7)$ & 0.0 \\
Cyprus & 1.4 & 1.6 & 5.9 & Netherlands & 7.3 & 5.0 & 12.9 \\
Czech Republic & 8.1 & 13.0 & 12.5 & Poland & 8.0 & 12.2 & 10.6 \\
Denmark & 1.5 & 5.5 & 12.2 & Portugal & $(0.4)$ & $(4.7)$ & 3.5 \\
Finland & 9.9 & 10.7 & 13.5 & Slovakia & 4.5 & $(10.3)$ & 8.4 \\
France & 10.7 & 18.0 & 16.4 & Slovenia & 7.6 & 8.5 & 18.4 \\
Germany & 11.9 & 17.0 & 14.1 & Spain & 12.5 & 20.8 & 19.7 \\
Great Britain & 8.7 & 16.1 & 13.6 & Sweden & 11.6 & 17.3 & 17.8 \\
\cline { 4 - 6 } Greece & 5.1 & $(5.3)$ & 4.6 & Median & $\mathbf{7 . 2}$ & $\mathbf{1 2 . 2}$ & $\mathbf{1 6 . 8}$ \\
Hungary & 1.0 & 3.1 & 8.6 & Mean & $\mathbf{9 . 4}$ & $\mathbf{1 3 . 4}$ & $\mathbf{1 3 . 8}$ \\
Ireland & 7.8 & 14.9 & 17.3 & Stand. deviation & $\mathbf{1 6 . 7}$ & $\mathbf{3 4 . 9}$ & $\mathbf{2 0 . 5}$ \\
\hline
\end{tabular}

Source: Author's analysis of company data from Albertina; in rows, legal domicile of the listed parents of Czech subsidiaries

As evidence from the aggregate data is mixed, the analysis has to be refined. Individual data are investigated for the existence of any heterogeneity in terms of the

\footnotetext{
${ }^{1}$ In many cases, small EBT (around zero) are adjusted to high tax profits, hence the high income taxes, thus resulting in exaggerated relative rates of taxation. The most extreme value was identified in year 2012, when it reached $219,316 \%$ for one company in the sample. The same story may
}

domicile of the parent which is used as a sorting variable for the following reasons (also outlined in the introduction). The quality of enforcement regimes differ across countries

apply for ROA as well as ROE, if total assets and total equity, respectively, are close to zero. 
which may strengthen/impair the parent's incentives to boost the performance of the group (Berger, 2010). Taxation varies across countries as well; the parent's location is used as a proxy to control for this potentially different incentive to shift profits (Heckemeyer \& Overesch, 2013). In addition, capital markets are distinct in their size and economic importance across EU countries (Prochazka \& Pelak, 2015) which may increase/decrease motivation of the listed companies to manage earnings, e.g., through profit shifting within the group. For each year observation, ROA, ROE, and ETR are calculated according to Formulas (1) - (3) with the results rounded to one decimal place. Country averages are computed as simple averages for all corresponding values. Table 2 shows unweighted country averages of ROA; unweighted averages of ROE and unweighted averages for ETR as well as summary statistics.

The best ROA scores are attained by Czech subsidiaries of Spanish parents (a 6-year average of $12.5 \%$ ), followed by firms under the control of German and Swedish parents (an average ROA of $11.9 \%$ and $11.6 \%$ ). In contrast, the worst performance is reported when Czech subsidiaries have listed parents in Malta (with a negative ROA $2.7 \%$ ), Portugal $(0.4 \%)$, and Hungary $1.0 \%$. The average scores of ROE display more variability than the ROA figures on both sides of the spectrum. Three subgroups report negative ROE, with the worst position being that of Maltese parents - a negative 6-year ROE average of $(35.7 \%)$ - followed by Czech subsidiaries of Slovakian parents (10.3\%) and Greek parents $(5.3 \%)$. In contrast, superior performance is once again presented by companies with parents located in Spain - positive ROE $20.8 \%$, France $18 \%$, and Sweden $17.3 \%$. The minimum average ETR is achieved by Czech companies under the control of listed companies at Malta a 6-year average ETR of $0.0 \%$; with Portugal standing at $3.5 \%$ and Greece at $4.6 \%$. On the other hand, most taxed Czech companies belong to MNE groups with headquarters in Croatia $22.9 \%$, Spain $19.7 \%$, and Slovenia $18.4 \%$. $^{2}$

\section{Inferential Analysis}

One limitation of the above analysis shall be mentioned: seven subtotals comprise less than 30 country-observations (namely Cyprus, Greece, Croatia, Malta, Hungary, Portugal, and Slovenia). The number of Czech entities under the control of listed companies from those countries is relatively small. The individual observations - despite being grouped together - can still be extreme outliers. A similar problem occurs for four industries ( $\mathrm{P}-$ Education; $\mathrm{Q}-$ Human health; $\mathrm{R}$ - Arts and entertainment; $\mathrm{S}$ - Other services). When only those countries, with more than 30 observations, are considered, the best performing Czech companies are subordinated to parents from Spain, Germany, and Sweden in terms of ROA and from Spain, France, and Sweden in terms of ROE. The worst performing subgroups regarding ROA are under the control of parents from Denmark, Slovakia, and Luxembourg, while Slovakia, Luxembourg, and the Netherlands constitute the worst performing subgroups under the ROE measure. The highest taxation is levied on companies controlled by Spanish, Swedish, and Irish parent companies. The lowest effective tax rates are faced to by Czech subsidiaries under the control of parent companies from Luxembourg, Slovakia, and Belgium.

Regarding the distribution across industries, the best performing (once again with at least 30 observations) are $\mathrm{K}$ - Financial services, M - Professional and scientific activities, and E - Water supply for ROA. In case of ROE, the top 3 industries are $\mathrm{K}$ - Financial services, $\mathrm{E}-$ Water, and $\mathrm{N}$ - Administrative and support services. On the other hand, the worst profitability measured by ROA is evidenced for A - Agriculture, L - Real estates, and F - Construction industry. If ROE is assessed, then I - Accommodation is on the tail end followed by $\mathrm{L}-$ Real estates and A Agriculture. Finally, N - Administrative and support services, B - Mining, and I - Accommodation are affected by the highest values of ETR. The lowest exposure to effective taxation can be traced to $\mathrm{L}-$ Real estates, $\mathrm{H}-$ Transportation and storage, and D - Utilities.

A factorial ANOVA test (Table 3) is run to verify whether the differences across subgroups are statistically significant. The ANOVA analysis employs data for subgroups with more than 30 country/industry observations only (i.e. seven country-domiciles and four industries are dropped out as described above). The restricted sample consists of 4,917 observations for 16 country-domiciles and 14 subsidiary-industries. The results of the factorial ANOVA tests indicate that the domicile of the parent has a significant impact (at a $1 \%$ significance level) on all three indicators. Similarly, industry variable is significant at a 1 $\%$ significance level (except for ETR, for which the association is significant "only" at a $5 \%$ level). Finally, the interaction term between parents' domiciles and industry affiliation of the subsidiaries is a factor as well. The hypotheses $\mathrm{H} 1$ and $\mathrm{H} 2$ are, thus, confirmed. As the analysis of variance reveals heterogeneity in performance both across industries and parents' jurisdiction, follow-up procedures - a correlation analysis and conditional decision trees - are implemented to diagnose the magnitude and sources of the differences.

When examining and comparing average scores within subgroups, several inconsistencies can be found. For example, Czech companies controlled by Belgian parents are No. 4 in ROA, but No. 9 in ROE, and even No. 14 in the case of ETR. Similarly, Irish parent companies controlling Czech firms ranked $12^{\text {th }}$ in ROA, $6^{\text {th }}$ in ROE, and $3^{\text {rd }}$ in ETR. On the other hand, the subgroup with Spanish parents is quite stable and consistent, as it is on the top of all three indicators. Both consistent and inconsistent rankings can be identified for industries as well. Bigger disproportions in the rankings are present when the subsidiary's industry is taken into account. In particular, the relationship between ROA and ETR is weak as just two industries (J, L) occupy similar positions. For all other industries, there is a of at least 4 places between the ROA and ETR rankings. A similar discrepancy is evident for the ROE and ETR pair.

\footnotetext{
${ }^{2}$ In the next step, a matrix of average values of ROA, ROE, and ETR for all "country-industry" combinations was computed. The outputs are not presented in the paper because of their complexity.
} 
Factorial ANOVA Tests

\begin{tabular}{|c|c|c|c|c|c|}
\hline ROA & Df & Sum sq & Mean sq & F-statistic & P-value \\
\hline Parent & 15 & $32,336.04$ & $2,155.74$ & 8.607 & $0.000 *$ \\
\hline Industry & 13 & $22,741.42$ & $1,749.34$ & 6.985 & $0.000 *$ \\
\hline Parent: Industry & 111 & $119,125.50$ & $1,073.20$ & 4.285 & $0.000 *$ \\
\hline Residuals & 4,777 & $1,196,432.15$ & 250.46 & & \\
\hline ROE & Df & Sum sq & Mean sq & F-statistic & P-value \\
\hline Parent & 15 & $143,447.55$ & $9,563.17$ & 8.699 & $0.000 *$ \\
\hline Industry & 13 & $59,860.02$ & $4,604.62$ & 4.188 & $0.000 *$ \\
\hline Parent: Industry & 111 & $530,308.86$ & $4,777.56$ & 4.346 & $0.000 *$ \\
\hline Residuals & 4,777 & $5,251,847.50$ & $1,099.40$ & & \\
\hline ETR & Df & Sum sq & Mean sq & F-statistic & P-value \\
\hline Parent & 15 & $33,104.71$ & $2,206.98$ & 5.380 & $0.000 *$ \\
\hline Industry & 13 & $11,017.84$ & 847.53 & 2.066 & $0.013^{* *}$ \\
\hline Parent: Industry & 111 & $89,511.38$ & 806.41 & 1.966 & $0.000 *$ \\
\hline Residuals & 4,777 & $1,959,729.80$ & 410.24 & & \\
\hline
\end{tabular}

These findings lead to the conjecture that performance and taxation behave independently across industries. A closer relation can be seen in the differences in rankings across a parent's domicile, albeit with some extreme values. To test the magnitude of association among rankings, the Spearman rho rank correlation test is run, and the outcomes are presented in Table 4. Performance and taxation is highly correlated when the parent's domicile is used as a sorting criterion indicating that higher performance (measured either by ROA and ROE) leads to a higher taxation (at least at the 5\% significance level). Contrariwise, the industry membership affects the association between ROA and ROE only. The values of correlation coefficients between ROA and ETR and between ROE and ETR are close to zero, thus confirming the conjecture about the independence of profitability and taxation in relation to industry affiliation of the Czech tax payer. This surprising outcome can be explained by two compounding effects: (a) high-profitable industries are able to reduce their taxation significantly; and, simultaneously, (b) less profitable or loss-making industries are subject of higher relative taxation. Based on the results of the analysis, mixed conclusions can be derived as far as $\mathrm{H} 3$ is concerned. There is a statistically significant association between performance and taxation when the parent's domicile is taken into account. However, the link is loose across the respective industries.

Correlation analysis (Spearman's Correlation Coefficients)

\begin{tabular}{|c|c|c|c|c|c|c|c|}
\hline Variable: Parent & $\begin{array}{c}\text { ROA } \\
\text { vs } \\
\text { ROE } \\
\end{array}$ & $\begin{array}{c}\text { ROA } \\
\text { vs } \\
\text { ETR } \\
\end{array}$ & $\begin{array}{c}\text { ROE } \\
\text { vs } \\
\text { ETR } \\
\end{array}$ & Variable: Industry & $\begin{array}{c}\text { ROA } \\
\text { vs } \\
\text { ROE }\end{array}$ & $\begin{array}{c}\text { ROA } \\
\text { vs } \\
\text { ETR } \\
\end{array}$ & $\begin{array}{c}\text { ROE } \\
\text { vs } \\
\text { ETR } \\
\end{array}$ \\
\hline Corr. coefficient & 0.785 & 0.565 & 0.715 & Corr. coefficient & 0.824 & -0.064 & 0.037 \\
\hline P-value & 0.000 & 0.023 & 0.002 & P-value & 0.000 & 0.829 & 0.899 \\
\hline
\end{tabular}

Source: Author's analysis using $R$

The correlation analysis is useful in detecting the general association between variables, the ANOVA test helps in the identification of explanatory variables causing a variance in the response variable. However, both tools are inconclusive when addressing whether any similar patterns among "influential observations" exist. An alternative method working with the algorithm of decision trees is, therefore, applied to check for similarities in differences. In particular, a method of conditional inference trees contained in R package "partykit" is processed. Figures 1-3 present the plots with tree splits. 
David Prochazka. Tax-in or Tax-out? Evidence from the Relation of Financial Performance and Effective Taxation of Czech...

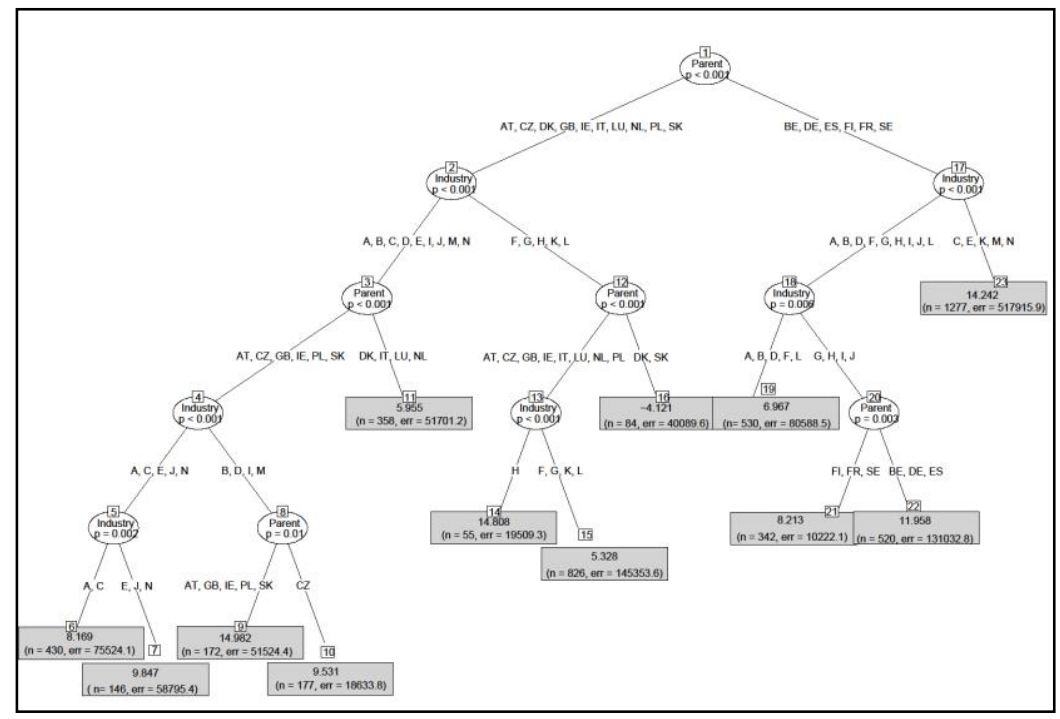

Figure 1. Conditional tree for ROA

Note: A-Agriculture; B-Mining; C-Manufacturing; D-Utilities; $E$ - Water supply; F-Construction; $G$ - Wholesale and retail; $H$

- Transportation; I-Accommodation; J-Information \& Communication; $K$-Financial services; L-Real estates; $M$ - Professional and scientific activities; $N$-Administrative services

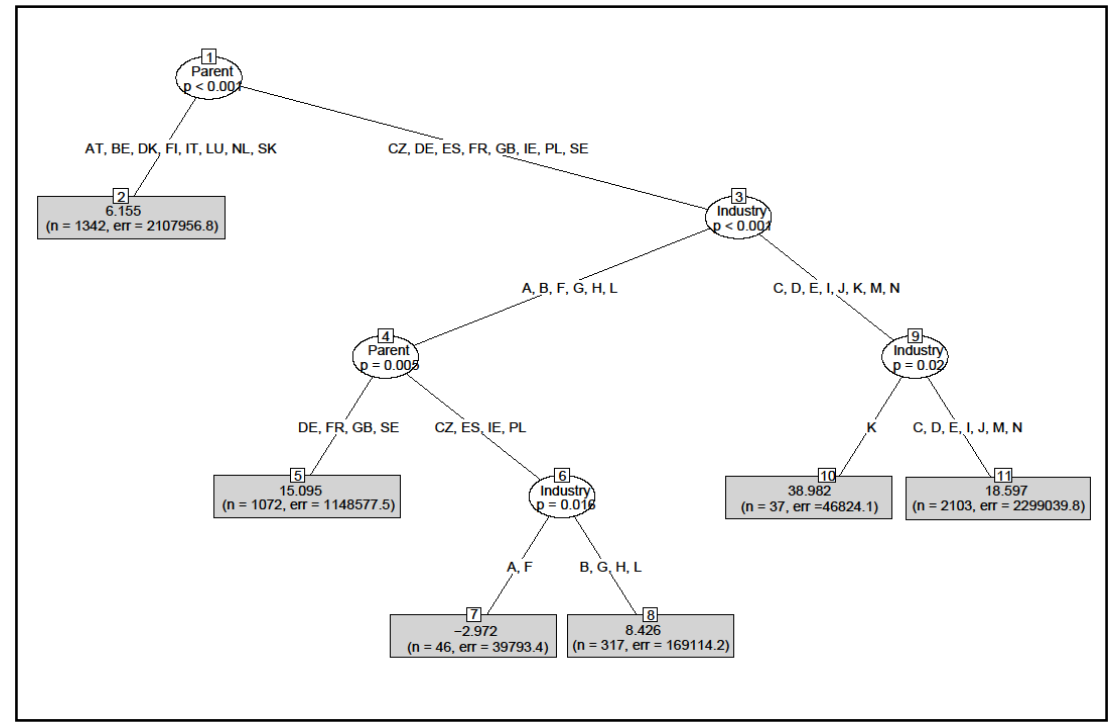

Figure 2. Conditional tree for ROE

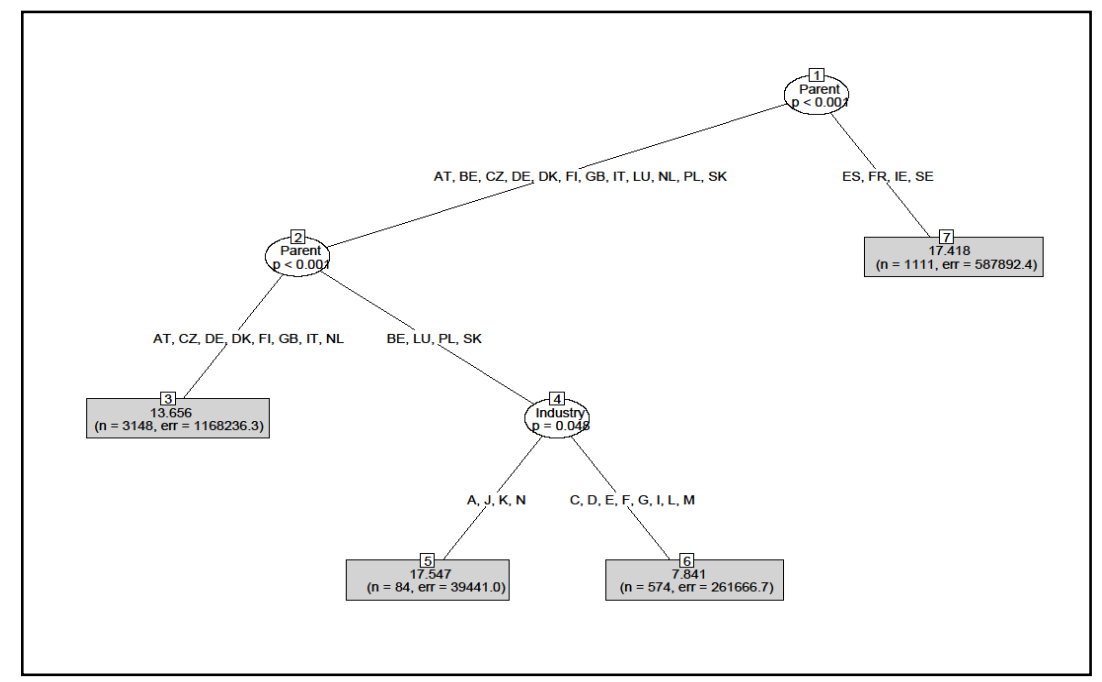

Figure 3. Conditional tree for ETR (Note: all three figures are author's analysis using R, package "partykit”) 
The most patulous tree is processed for ROA with the tree consisting of 12 terminal nodes structured up to 5 levels. The interaction between parent domiciles and subsidiary industries is complex. In the first step, the parent domicile is identified as the most influential factor and splits into two intermediate nodes. The node on the right side of the plot contains Czech companies with the parents located in 6 countries - in Belgium, Germany, Spain, Finland, France, and Sweden (abbreviations BE, DE, ES, FI, FR, SE), with other splits on lower levels. The remaining 10 parent domiciles are developed on the left-hand side of the plot. The best performance is reported by Czech companies under Node 9 (172 firms with an average ROA $=14.982 \%$ ), which (a) are controlled by Austrian, British, Irish, Polish, or Slovak parent companies and, simultaneously, (b) operate in following industries B - Mining, D - Utilities, I Accommodation, $\mathrm{M}$ - Professional and scientific activities. The second-best subgroup belongs to Node 14 (55 firms, $\mathrm{ROA}=14.808 \%$ ) covering firms from $\mathrm{H}-$ Transportation and storage under the control of parents from 8 different countries (AT, CZ, GB, IE, IT, LU, NL, PL). The third-best performing is Node $23(\mathrm{ROA}=14.242 \%)$, which is also the largest comprising as it does 1,277 firms.

Interesting findings also occur at the other end of the spectrum. The worst performing node is Node 16; a negative average ROA of (4.121\%) is experience by 84 companies under Danish and Slovak control conducting their business in $\mathrm{F}-$ Construction, $\mathrm{G}-$ Wholesale and retail, $\mathrm{H}-$ Transportation and storage, $\mathrm{K}$ - Financial services, or L Real estates industry. The plot for ROA reveals the main strength of the conditional inferential trees method. It allows for non-additive interactions between variables, thus uncovering seemingly paradoxical situations. For example, Slovak parent companies are represented both in the bestperforming (Node 9) and the worst-performing subset (Node 16). Similarly, H - Transportation industry is presented in the worst subgroup and the second-best performing node, Node 14.

Simpler tree structures can be seen with ROE and ETR. The conditional inferential tree for ROE consists of 6 terminal nodes split into 3 levels. Once again, the parent domicile is the first influential variable defining the split of the highest level. Unlike the ROA-tree, the initial decomposition creates different subgroups of companies both highest subsets cover controlling shareholders from 8 countries. The best performance expressed as ROE is $38.982 \%$ (Node 10) and it is attained by 37 firms in $\mathrm{K}$ Financial services sector when Czech subsidiaries are controlled either by domestic owners, or by owners from Germany, Spain, France, Great Britain, Ireland, Poland, Sweden. The best node is relatively small, similarly to the worst subgroup (Node 7), which comprises 46 firms from A - Agriculture and F - Construction industry (under the control of $\mathrm{CZ}, \mathrm{ES}, \mathrm{IE}, \mathrm{PL}$ ) with an average negative ROE $(2.972 \%)$.

The ETR-tree has 4 terminal nodes. The parent domicile is a dominant determinant of the differences/similarities across companies. Companies with the highest ETR, 17.547 $\%$, are formed under Node 5, operating in A - Agriculture, $\mathbf{J}$ - Information and communication, $\mathrm{K}$ - Financial services and $\mathrm{N}$ - Administrative and support services and being controlled by shareholders from Belgium, Luxembourg, Poland or Slovakia. A comparable level of taxation, regardless of the industry, occurs with Czech companies having parents located in Spain, France, Ireland, or Sweden. When interpreting a mutual relation among all three trees, we can conclude that the variable Parent is significant when explaining variation in both performance and taxation, but the variable Industry co-determines performance only. This corresponds to the findings of correlation analysis presented in Table 4.

\section{Conclusions}

The paper assesses the income tax behaviour of Czech entities under the control of companies listed in the EU by analysing the relation between financial performance and effective tax rates reported in their annual reports. Summary statistics of individual corporate data indicate that both the domicile of the parent and the industry affiliation of the subsidiary have an impact on the subsidiary's performance and its effective tax rate. The association of the parent domicile and the subsidiary industry with performance and taxation is also confirmed by the analysis of variance (factorial ANOVA). However, the method of conditional inference trees offers a more detailed view with substantially different findings. The industry effect, in addition to the domicile, is still relevant as far as the performance of Czech subsidiaries is concerned. Contrariwise, effective tax rates are influenced prevailingly the parent domicile where industry affiliation has no impact. In combination with the findings of high variability in relative tax rates, the results of conditional inference trees provide empirical evidence that a significant number of groups listed in the EU (mainly with the parents located in Western and the Northern Europe) prefer to transfer foreign profits to the Czech Republic rather than to shift Czech profits out of the country. On the other hand, effective taxation of Czech subsidiaries under the control of shareholders from Southern EU states is considerably lower than the taxation of domestically controlled firms.

Empirical data reveal that multinational enterprises from significantly richer EU countries opt to shift profits to the Czech Republic which has lower corporate income tax rates resulting in greater profits compared to the real performance of controlled subsidiaries. On the other hand, those parent companies located in countries with comparable or worse economic levels allot energy and resources to avoid taxation in the Czech Republic. These findings have three major practical implications. Firstly, the tax authorities shall intensely focus attention on those Czech companies having a parent in tax havens or in countries with generally low tax discipline and imperfect enforcement. The local tax practices of these parents are imported and utilised by their Czech subsidiaries as well. Secondly, policy makers shall continue in building a favourable tax infrastructure as there are inflows of additional profit from abroad in those MNE groups which are managed by parents located in richer (developed) countries. Combining both tax-compliance measures and tax incentives may significantly boost tax revenue, as recent research shows that MNEs headquarters exploit regulatory arbitrage opportunities arising from 
cross-country differences in institutional quality to manage earnings, including through tax optimisation (Beuselinck, Cascion, Deloof \& Vanstraelen, 2018). Both findings can be relevant not only for Czech government, but also for other transition countries relying on foreign direct investments. Thirdly, the unclear depiction of financial performance (overstated or understated due to profit shifting within the group) in published financial figures of subsidiaries emphasises the increased information risks of any "outside user" of individual financial statements of companies controlled by other entities. Requiring consolidated financial statements of the group is then genuinely necessary to make any reasonable decision about the subsidiary.

The paper uncovers new research questions yet to be answered. Future research shall, therefore, address the main determinants of corporate taxation of Czech subsidiaries under foreign control. In particular, the factors considered by parents when deciding whether to tax their profits in or out of the Czech Republic are of the utmost interest. This stream of research can be especially useful for the government and other policy makers. Further research is also needed to disentangle whether the transfer of practices from the parent to subsidiary is the main contributor of improved financial performance of affected subsidiaries and whether the improved performance is accompanied by higher relative taxation. An alternative explanation can be that the favourable Czech tax regime promotes the profit shifting to Czech subsidiaries and increased performance reported in financial statements is just an inevitable consequence, but without real grounds. Investigating this area can produce valuable findings for users of financial statements. Our conclusions supports similar concerns of Bonacchi et al. (2018) about the usefulness of financial statements of non-listed subsidiaries. Their study identifies that financial statements of subsidiaries are negatively affected by earnings management driven by their listed parent companies to meet or beat capital market benchmarks. Our study complements these concerns by identifying that profit shifting within MNE groups is an additional source of negative effects impairing the quality of financial statements of subsidiaries. Finally, future studies shall extend the scope of the investigation by focusing not only on companies listed in the EU, but including all foreign investors present in the Czech Republic. Similarly, a wide international comparison is recommended as well, as profit shifting within MNEs through subsidiaries is a general problem relevant (not only) to all transition countries of the Central and Eastern Europe.

\section{Acknowledgements}

This paper has been prepared within the research project "Textual Analysis of Financial Statements" (supported by the Grant Agency of the University of Economics, Prague; No. F1/18/2018).

\section{References}

Albu, N., Lupu, I., \& Sandu, R. (2014). Multinationals as vectors of corporate governance improvement in emerging economies in Eastern Europe: A case study. In S. Boubaker \& D. K. Nguyen (Eds.), Corporate governance in emerging markets (pp. 331-349). Berlin, Heidelberg: Springer Berlin Heidelberg. https://doi.org/10.1007/978-3-64244955-0_13

Ali, A., \& Hwang, L.-S. (2000). Country-specific factors related to financial reporting and the value relevance of accounting data. Journal of Accounting Research, 38(1), 1-21. https://doi.org/10.2307/2672920

Atwood, T. J., Drake, M. S., \& Myers, L. A. (2010). Book-tax conformity, earnings persistence and the association between earnings and future cash flows. Journal of Accounting and Economics, 50(1), 111-125. https://doi.org/10. 1016/j.jacceco.2009.11.001

Berger, A. (2010). The development and status of enforcement in the European Union. Accounting in Europe, 7(1), 15-35. https://doi.org/10.1080/17449480.2010.485388

Berman, S. L., Wicks, A. C., Kotha, S., \& Jones, T. M. (1999). Does stakeholder orientation matter? The relationship between stakeholder management models and firm financial performance. Academy of Management Journal, 42(5), 488-506. https://doi.org/10.2307/256972

Beuselinck, C., Cascino, S., Deloof, M., \& Vanstraelen, A. (2018). Earnings management within multinational corporations. The Accounting Review, Forthcoming. https://doi.org/10.2308/accr-52274

Blaylock, B., Gaertner, F., \& Shevlin, T. (2015). The association between book-tax conformity and earnings management. Review of Accounting Studies, 20(1), 141-172. https://doi.org/10.1007/s11142-014-9291-X

Bonacchi, M., Cipollini, F., \& Zarowin, P. (2018). Parents' use of subsidiaries to "push down" earnings management: Evidence from Italy. Contemporary Accounting Research, 35(3), 1332-1362. https://doi.org/10.1111/19113846.12330

De Simone, L. N. (2016). Does a common set of accounting standards affect tax-motivated income shifting for multinational firms? Journal of Accounting and Economics, 61(1), 145-165. https://doi.org/10.1016/j.jacceco.2015.06.002

Desai, M. A. (2005). The degradation of reported corporate profits. Journal of Economic Perspectives, 19(4), 171-192. https://doi.org/10.1257/089533005775196705 
Diamond, P. A., \& Mirrlees, J. A. (1971). Optimal taxation and public production II: Tax rules. The American Economic Review, 61(3), 261-278.

Durnev, A., Li, T., \& Magnan, M. (2017). Beyond tax avoidance: Offshore firms' institutional environment and financial reporting quality. Journal of Business Finance \& Accounting, 44(5/6), 646-696. https://doi.org/10.1111/jbfa.12240

Dyreng, S. D., Hanlon, M., \& Maydew, E. L. (2008). Long-run corporate tax avoidance. The Accounting Review, 83(1), 61-82. https://doi.org/dx.doi.org/10.2308/accr.2008.83.1.61

Ernest, J. (2014). Cesky prumysl je "nas" jen z poloviny (Only half of the Czech industry is "ours"). Statistika\&My, 4(10), $18-19$.

Fang, Y., Jiang, G.-L. F., Makino, S., \& Beamish, P. W. (2010). Multinational firm knowledge, use of expatriates, and foreign subsidiary performance. Journal of Management Studies, 47(1), 27-54. https://doi.org/10.1111/j.14676486.2009.00850.x

Fang, Y., Wade, M., Delios, A., \& Beamish, P. W. (2007). International diversification, subsidiary performance, and the mobility of knowledge resources. Strategic Management Journal, 28(10), 1053-1064. https://doi.org/10.1002/smj.619

Fey, C. F., \& Bjorkman, I. (2001). The effect of human resource management practices on MNC subsidiary performance in Russia. Journal of International Business Studies, 32(1), 59-75. https://doi.org/10.1057/palgrave.jibs.8490938

Frank, M. M., Lynch, L. J., \& Rego, S. O. (2009). Tax reporting aggressiveness and its relation to aggressive financial reporting. The Accounting Review, 84(2), 467-496. https://doi.org/dx.doi.org/10.2308/accr.2009.84.2.467

Gaur, A. S., Delios, A., \& Singh, K. (2007). Institutional environments, staffing strategies, and subsidiary performance. Journal of Management, 33(4), 611-636. https://doi.org/10.1177/0149206307302551

Hanlon, M., Laplante, S. K., \& Shevlin, T. (2005). Evidence for the possible information loss of conforming book income and taxable income. Journal of Law and Economics, 48(2), 407-442. https://doi.org/10.1086/497525

Hanlon, M., Maydew, E. L., \& Shevlin, T. (2008). An unintended consequence of book-tax conformity: A loss of earnings informativeness. Journal of Accounting and Economics, 46(2/3), 294-311. https://doi.org/10.1016/j.jacceco.20 08.09.003

Hanlon, M., \& Shevlin, T. (2005). Book-tax conformity for corporate income: An introduction to the issues. NBER/Tax Policy \& the Economy (MIT Press), 19(1), 101-134. https://doi.org/10.1086/tpe.19.20061897

Heckemeyer, J. H., \& Overesch, M. (2013). Multinationals' profit response to tax differentials: Effect size and shifting channels. (No. 13-045) (p. 37). ZEW Discussion Papers. https://doi.org/10.2139/ssrn.2303679

Hicks, J. R. (1946). Value and capital: An inquiry into some fundamental principles of economic theory. Oxford: Clarendon Press.

Hoffmann, S., \& Zulch, H. (2014). Lobbying on accounting standard setting in the parliamentary environment of Germany. Critical Perspectives on Accounting, 25(8), 709-723. https://doi.org/10.1016/j.cpa.2014.04.003

Hothorn, T., Hornik, K., van de Wiel, M. A., \& Zeileis, A. (2006). A Lego system for conditional inference. The American Statistician, 60(3), 257-263. https://doi.org/10.1198/000313006X118430

Huizinga, H., \& Laeven, L. (2008). International profit shifting within multinationals: A multi-country perspective. Journal of Public Economics, 92(5/6), 1164-1182. https://doi.org/10.1016/j.jpubeco.2007.11.002

Kostova, T., \& Roth, K. (2002). Adoption of an organizational practice by subsidiaries of multinational corporations: Institutional and relational effects. Academy of Management Journal, 45(1), 215-233. https://doi.org/10.2307/3 069293

Kucera, L. (2015). Odliv dividend zesilil (Dividends outflows intensified). Statistika\&My, 5(06/2015), 18.

Lang, M., Lins, K. V., \& Maffett, M. (2012). Transparency, liquidity, and valuation: International evidence on when transparency matters most. Journal of Accounting Research, 50(3), 729-774. https://doi.org/10.1111/j.1475679X.2012.00442.x

Luo, Y. (2003). Market-seeking MNEs in an emerging market: How parent subsidiary links shape overseas success. Journal of International Business Studies, 34(3), 290-309. https://doi.org/10.1057/palgrave.jibs.8400027

Manzon, G. B., \& Plesko, G. A. (2001). The relation between financial and tax reporting measures of income. Tax Law Review, 55, 175-214. https://doi.org/10.2139/ssrn.264112

Mills, L. F., Newberry, K. J., \& Trautman, W. B. (2002). Trends in book-tax income and balance sheet differences. Tax Notes, 96(8), 1109-1124. https://doi.org/10.2139/ssrn.313040 
David Prochazka. Tax-in or Tax-out? Evidence from the Relation of Financial Performance and Effective Taxation of Czech...

Oliver, C. (1991). Strategic responses to institutional processes. Academy of Management Review, 16(1), 145-179. https://doi.org/10.5465/AMR.1991.4279002

Orlitzky, M., Schmidt, F. L., \& Rynes, S. L. (2003). Corporate social and financial performance: A meta-analysis. Organization Studies, 24(3), 403-441. https://doi.org/10.1177/0170840603024003910

Prochazka, D., \& Molin, J. (2016). Book-tax conformity: the review of recent research and its implication for the IFRS adoption in Europe. EJournal of Tax Research, 14(1), 96-118.

Prochazka, D., \& Pelak, J. (2015). The development of capital markets of new EU countries in the IFRS era. Procedia Economics and Finance, 25, 116-126. https://doi.org/10.1016/S2212-5671(15)00720-0

Strasser, H., \& Weber, C. (1999). On the asymptotic theory of permutation statistics. Mathematical Methods of Statistics, $8(2), 220-250$.

Svitlik, J. (2015). ETR development and analysis: Case from the Czech Republic. European Financial and Accounting Journal, 2015(4), 05-18. https://doi.org/10.18267/j.efaj.146

Watrin, C., Ebert, N., \& Thomsen, M. (2014). Book-tax conformity and earnings management: Insights from European one- and two-book systems. The Journal of the American Taxation Association, 36(2), 55-89. https://doi.org/dx.doi. org/10.2308/atax-50769

Whitaker, C. (2005). Bridging the book-tax accounting gap. The Yale Law Journal, 115(3), 680-726.

Yang, Q., Mudambi, R., \& Meyer, K. E. (2008). Conventional and reverse knowledge flows in multinational corporations. Journal of Management, 34(5), 882-902. https://doi.org/10.1177/0149206308321546

The article has been reviewed.

Received in March 2018; accepted in June 2019. 